\title{
EXPERIMENTAL RESULTS FROM CEM-UT'S SINGLE SHOT 9 MJ RAILGUN
}

R. J. HAYES AND R. C. ZOWARKA, JR.

Presented at the

5th Symposium on Electromagnetic

Launch Technology

Eglin AFB, Florida

April 2-5, 1990

Publication No. PR-111

Center for Electromechanics

The University of Texas at Austin

Balcones Research Center

EME 1.100, Building 133

Austin, TX 78758-4497

(512) $471-4496$ 


\author{
R.J. Hayes and R.C. Zowarka ,Jr. \\ Center for Electromechanics \\ The University of Texas at Austin \\ 10100 Burnet Rd. Bldg. 133 \\ Austin, TX 78758-4497
}

\begin{abstract}
The Center for Electromechanics at the University of Texas at Austin (CEM-UT) has designed and fabricated a $10-\mathrm{m}$ long $90 \mathrm{~mm}$ bore railgun. During the test program, a number of solid armatures and projectile packages have been tested in a $50 \mathrm{~m}$ deep vertical test range. The experiments are powered by six homopolar generator (HPG) charged inductive stores, sequentially staged to provide the desired acceleration profile. Prior to testing, computer simulations are run to determine the preferred current profile and predict system performance. During projectile flight, high speed films, x-rays, muzzle volts, and velocity/acceleration profiles are recorded along with power supply operating parameters. Postshot diagnostics include bore wear analysis and armature and target recovery. Comparisons of predicted and recorded shot performance are also made. On selected tests, an energy balance is performed to determine efficiencies of the various system components. A summary of all $90 \mathrm{~mm}$ gun shots is presented along with critical data collected from selected tests.
\end{abstract}

\section{Vertical Gun Range}

The vertical gun range at CEM-UT is $50 \mathrm{~m}$ deep and $4.3 \mathrm{~m}$ in diameter, except for the top two levels which are $6 \mathrm{~m}$ in diameter. The gun range is located approximately $10 \mathrm{~m}$ from the center of the $60 \mathrm{MJ}$ Balcones HPG power supply. A multilayer aluminum busbar, 11-m long, carries the current to the gun. The $10 \mathrm{~m}$ long railgun is located on the ground floor of the range and extends into the second level below grade (level two). In addition to the ground floor there are nine levels below grade, where diagnostics can be accommodated, and a target chamber. A $1 \mathrm{~m}$ diameter steel flight tube $3.8 \mathrm{~cm}$ thick prevents projectiles from damaging diagnostic equipment. Access windows are located in four locations around the flight tube on levels two through nine. An elevator is available for transporting tools and personnel to the lower levels of the test facility. A 30 ton overhead crane is used to load targets into the target chamber.

Diagnostics in the range include four Scandiflash $^{\mathrm{TM}} 300 \mathrm{kV}$ flash $\mathrm{x}$-ray units which may be triggered by muzzle volts, B-dot signals or breaking a fiber optic cable. Four high speed $16 \mathrm{~mm}$ Photonic ${ }^{\mathrm{TM}}$ Photec IV, rotating prism cameras capable of 20,000 frame/s operation are triggered by the generator control system. Rippleflash units for back or front lighting are also available. Four $35-\mathrm{mm}$ cameras with laser gate triggers can be used for in-flight shadowgraphs. Pressure transducers mounted in the flight tube, in the target chamber, and at several levels in the range may be used to monitor overpressure produced during gun shots. In-bore diagnostics include gun current, breech and muzzle volts, and B-dots. Rogowski coils and active integrator systems monitor generator, inductor, and switch currents, in addition to busbar currents at several locations. Generator, switch, and busbar volts are also recorded. In all, 24-oscilloscope channels and 24-digitizer channels are available to monitor the critical parameters. The data is downloaded onto a VAX 11/750 minicomputer where CEM-UT developed software is used to manipulate the raw data into a usable format. By reviewing the data collected from each shot, it is possible to determine the preferred generator and switch parameters and tailor a current profile for a particular launch package. This information is used by computer models developed at CEM-UT to simulate potential tests based on previous experiments.

\section{Gun Assembly}

The $90-\mathrm{mm}$ bore, $10 \mathrm{~m}$ long gun uses a replaceable rail assembly constructed of four $90^{\circ}$ sectors. The L' of the $90-\mathrm{mm}$ gun has been measured at $0.37 \mu \mathrm{H} / \mathrm{m}$. The gun design and rail replacement technique was initially confirmed through testing of a half-scale ( $45-\mathrm{mm}$ bore) gun, 3-m long. Fabrication and testing of the $45-\mathrm{mm}$ gun proved invaluable in making preparations for the full-scale gun. The two copper rail sectors in both the half and full-scale gun were made from full length extrusions of ETP 110 copper. Insulator sections were cut from a wound composite tube comprised of room temperature amine cure epoxy and E-glass fibers. After machining the rail/insulator package to an $18-\mathrm{cm}$ Outside Diameter (OD), it was inserted into a rail support structure, composed of ceramic disks which are hydraulically prestressed after loading the rail assembly. This is accomplished by pressurizing an annulus of fluid between the $11.6 \mathrm{~cm}$ thick steel pressure vessel and the $2.5 \mathrm{~cm}$ thick compression sleeve to 224 MPa (32.5 kpsi). The result of this prestress is a $90 \mathrm{~mm}$ gun bore that deflects approximately the same amount as a $120 \mathrm{~mm}$ conventional smooth bore powder gun at peak bore pressure, (fig. 1).[1] Reduced bore deflection ensures better armature contact which in turn results in increased performance and reduced bore wear.[2]

\begin{tabular}{|c|c|c|c|}
\hline \multirow[b]{2}{*}{ RAILGUN BORE } & \multirow[b]{2}{*}{$\begin{array}{l}\text { CONVENTIONAL } \\
\text { SMOOTH BORE } \\
\text { POWDER GUN }\end{array}$} & \multicolumn{2}{|c|}{$\begin{array}{l}\text { HYDRAULICALLY } \\
\text { PRELOADED } \\
\text { CERAMIC }\end{array}$} \\
\hline & & $\begin{array}{c}\text { EM GUN } \\
\text { COPPER } \\
\text { RAILS }\end{array}$ & $\begin{array}{c}\text { EM GUN } \\
\text { MOLYBDENUM } \\
\text { RAILS }\end{array}$ \\
\hline $\begin{array}{l}\text { DEFLECTION } \\
\mathrm{mm} \text {, (inches) }\end{array}$ & $0.228(0.009)$ & $0.284(0.011)$ & $0.204(0.008)$ \\
\hline $\begin{array}{l}\text { BORE DIAMETER } \\
\mathrm{mm}\end{array}$ & 120 & 90 & 90 \\
\hline $\begin{array}{l}\text { PEAK PRESSURE } \\
\mathrm{MPa} \text { ( }(\mathrm{ksi})\end{array}$ & $481 \quad(69.8)$ & $373 \quad(54.1)$ & $373(54.1)$ \\
\hline
\end{tabular}

Figure 1. Comparison of bore deflections in conventional and EM guns 


\section{Bore Wear Analysis}

After each test, the bore of the gun is honed to ensure a round uniform bore for the next test. The honing process removes between 0.050 and $0.100 \mathrm{~mm}$ $(0.002$ and 0.004 in.) from the surface of each rail and insulator $(0.100$ to $0.200 \mathrm{~mm}$ on the diameter). The material removed is not a result of bore wear, but is part of the effort to maintain consistent bore conditions for each test. Typically, after a shot, the bore size will not have increased at all. In fact, a thin layer of aluminum powder may actually make the Inside Diameter (ID) measure slightly smaller than prior to the shot. To remove this powder and assure a clean consistent ID, the bore is honed to a slightly larger diameter. This is generally adequate to return the rails to their preshot condition. Bore condition is verified by videotaping the entire bore prior to each shot with an in-bore camera.

On some shots, more material has been removed to clean up localized damage to the insulators. This is a result of the type of material used for the sidewalls. The fiberglass tube was not wound in a continuous manner, but was wound in layers approximately 1/8-in. thick and then allowed to partially cure before continuing the winding process. These layers do not adequately adhere to one another which allows the layers closest to the ID of the bore to peel off if they are exposed to impact or shearing forces. Once a small section of insulator fails, it provides an initiation point for this peeling or delamination to continue on future shots. As a temporary solution to this problem, a method to fill the damaged areas in the insulators has been devised and implemented. It involves grinding out the damaged areas and then repotting them with a glass-filled epoxy. This type of repair is sufficient for several shots, but eventually the parent material behind the patched area begins to delaminate again. A complete full-length repair may be implemented before installing a replacement set of rails and insulators. When the next set of rails and insulators are installed, pultruded glass insulators which are made in full lengths with a homogeneous cross section will be used to replace the present insulators. This higher strength material should substantially decrease the amount of insulator damage seen during a gun shot. Other materials such as pressure laminated fiberglass mat/epoxy composites and ceramics are also being investigated.

Pitting in the copper rails seems to be the result of arc erosion and/or high-speed gouging.[3] This damage is shallow, less than $1 \mathrm{~mm}$ in depth, less frequent than the insulator damage, and is more random in nature. It is often seen on the rails just beyond the damaged areas in the insulators. It appears that some of the failing insulator material may get blown out ahead of the armature and cause the contacts to arc or gouge the rails as they run over the loose material. This damage does not get worse from shot to shot. Still, new harder materials are being pursued for use as rails. Potential candidates include several high strength copper alloys. Molybdenum alloys, with even greater strength, hardness, and stiffness are also being considered. Rails, which are harder than the armature material, will decrease wear.

Another important factor affecting bore wear is the type of armature/projectile package fired and its condition at exit. Armature boreriders and sabots have occasionally failed in-bore. A single projectile failure in-bore can initiate insulator damage in a dozen locations. All of these factors contribute to damage in the rails and insulators. As the integrity of the packages becomes more consistent, the life of the gun bores will increase correspondingly.

\section{Armature Design}

Solid aluminum armatures of 7075 alloy are used as complete launch packages and to launch test packages provided by outside projectile developers such as Kaman Sciences and Ford Aerospace. Figures 2 and 3 illustrate typical long and short armatures, respectively. The objective of the solid armature design is to provide an adequate contact surface with good mechanical compliance, while maintaining sufficient current carrying capability. This is accomplished by machining a 50 -minute taper into the $5 \mathrm{~cm}$ long contact surface, which results in a $1.5 \mathrm{~mm}$ interference fit on the diameter at the rear of the contact and a line-to-line fit at the front. Loading armatures with this type of an interference fit requires an insertion force of 50 to $150 \mathrm{kN}$ $(11,000$ to $33,750 \mathrm{lb})$. This assures that the contacts are adequately loaded against the rails for the initial surge of current which starts the armature moving from its static position. Because the armature is designed with compliance in mind, as it moves down the bore and the contacts are worn away the magnetic pressure continues to force additional contact material against the rails.

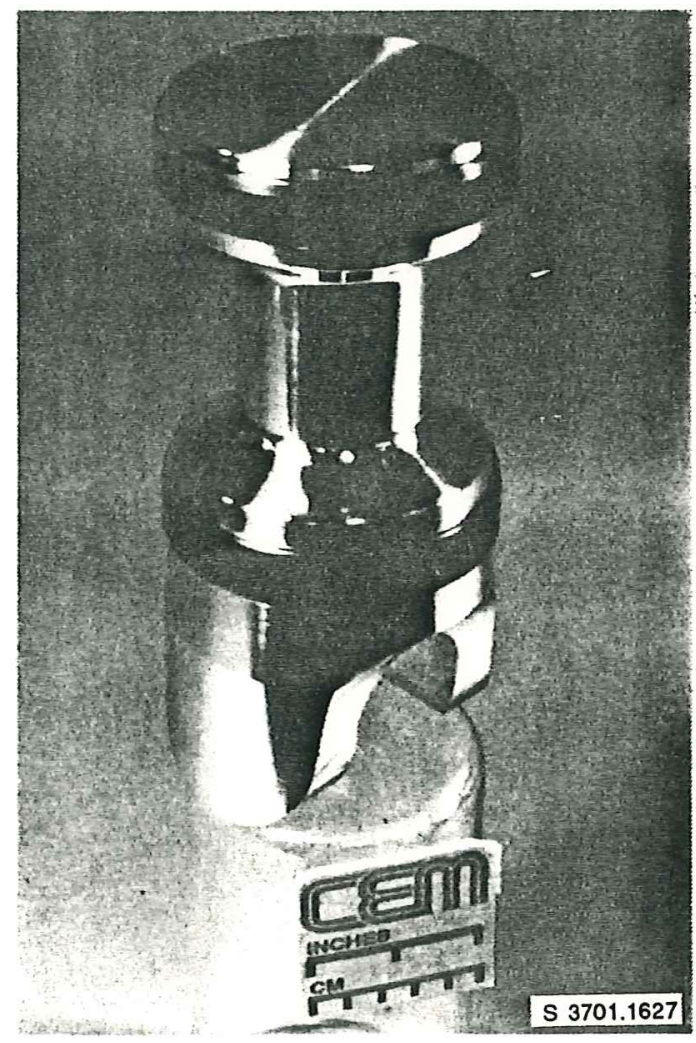

Figure 2. Long nose solid aluminum armature fired at $2,300 \mathrm{~m} / \mathrm{s}$ on shot \#11 in $90-\mathrm{mm}$ gun

As an additional aid in maintaining armature contact, front and rear boreriders are used on the "longneck" armatures, which carry an integral payload. The boreriders are machined rings of nylon which are elastically expanded over the armature until they reach a machined borerider groove and shrink to their final internal dimension. The rings are machined to provide 


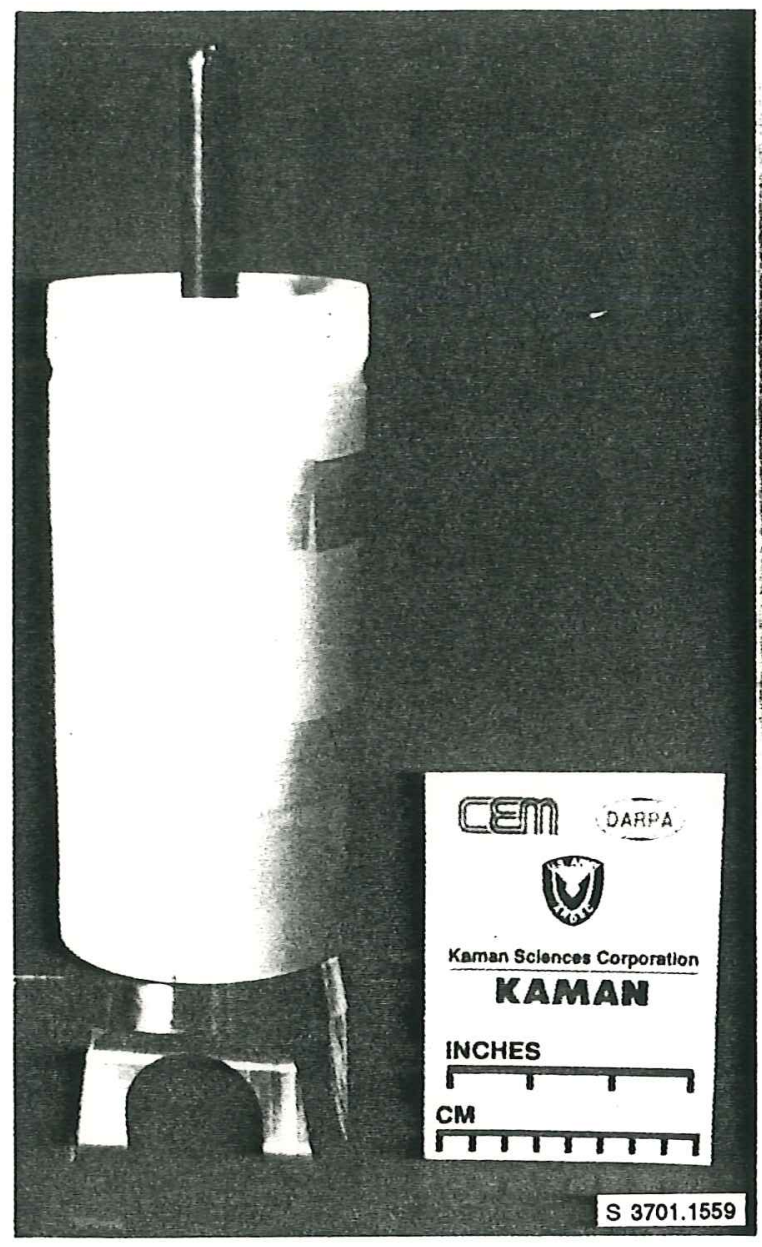

Figure 3. Kaman Sciences separating sabot and steel projectile launched by snubnose armature on shot \#6 in 90 -mm gun

a $2.5 \mathrm{~mm}$ interference fit between the borerider ID and the retaining groove OD and a line-to-line fit between the borerider $\mathrm{OD}$ and the gun bore. The use of a front borerider was initially begun during testing of the 45 $\mathrm{mm}$ gun when it was noted, on shot \#7, that two closely linked B-dot signals or "a doublet" indicated that the nose of the projectile was carrying current. This was verified by measuring the time between the two B-dot peaks which, when multiplied by the velocity of the armature, equalled the distance between the nose of the armature and the rear contact. Adding the front borerider eliminated the B-dot doublets. The doublets reoccured on shot \#12 of the $90 \mathrm{~mm}$ gun when the frontborerider apparently failed and allowed the nose to carry current. This was confirmed again by measuring the time between the B-dot signal, converting to a distance and comparing it to the nose-to-contact dimension. There is no evidence in the B-dot traces of a leading or trailing plasma arc.

A rear borerider was added on shot \#10 of the 90-mm gun in an effort to assure that both armature contacts maintain contact with the rail. Without a centering device, such as the borerider, one contact could possibly be pulled out of contact as the other contact is forced into the rail. The centering effect is especially important when the armature begins to transition and the rear contacts are no longer providing stability. The other benefit of the rear borerider is as a plasma seal. Muzzle volts vs. velocity plots, figure 4, have been generated for all the $90 \mathrm{~mm}$ gun shots, which exceeded $1,800 \mathrm{~m} / \mathrm{s}$. These plots confirm that the armatures transition between 750 and $1,100 \mathrm{~m} / \mathrm{s}$. Because solid armatures do transition to a hybrid solid/plasma armature, [4] it is important to address the issues relevant to both types of armatures in the solid armature design. This becomes particularly important when launching projectile packages utilizing a short or "snubnose" armature.

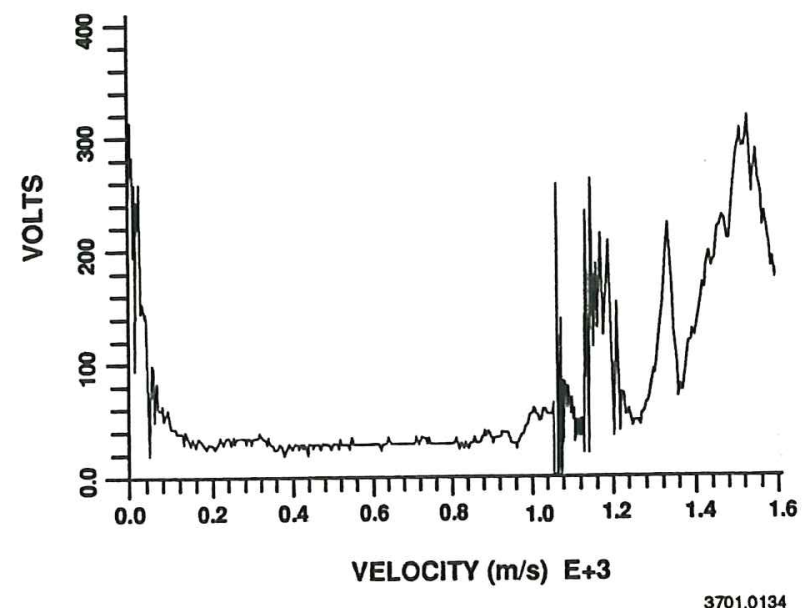

Figure 4. Muzzle volts vs. velocity for shot \#9 of $90-\mathrm{mm}$ gun

Tests of short armatures weighing less than a $\mathrm{kg}$ pushing saboted penetrator packages weighing up to 1.7 $\mathrm{kg}$, indicate that the solid armature is a reliable and efficient mechanism for launching such packages. These armatures are basically the rear half of a "longneck" armature with the borerider removed. To provide a locating surface for the sabot, an inverse locking taper is machined onto a $19 \mathrm{~mm}$ long pilot stub on the nose of the armature. The sabot is locked to this pilot by machining a matching, tapered counterbore into its base. The sabot, if firmly attached, provides adequate stabilization for the shortened armature. It is important, however, that sufficient attention be given to the interface between the armature nose and sabot base. Plasma leakage into this area can separate the sabot from the armature if the sabot is not adequately locked to the armature. The addition of a borerider ahead of the contacts may be advantageous in reducing plasma leakage and stabilizing shorter armatures during future tests.

\section{Armature Performance}

To establish baseline parameters for armature contact design, calculations based on the heating of the armature during high current tests have been done.[5] The calculations are based on Joule's law which provides for the calculation of the amount of heat developed in a conductor of a known resistance when a given amount of current passes through the conductor for a finite amount of time.

$$
\epsilon=\int j^{2} \rho_{E} d t
$$


Separating the physical properties from the circuit parameters defines the action integral which is on the right hand side of equation (1).

$$
\int_{T_{0}}^{T_{f}} \frac{d \in}{\rho_{E}}=\int_{0}^{t_{f}} j^{2} d t
$$

With the physical parameters separated, it is possible to determine a minimum cross-sectional area for a given current vs. time profile or to determine the final temperature of a particular conductor after it has carried a finite amount of current for a given time duration. Using the second method, the maximum temperatures reached by solid armatures in the $90-\mathrm{mm}$ gun have been calculated. This information is used in the armature design phase to establish a minimum cross-sectional area for an armature conduction path. In the steady state heating of aluminum, the material can lose over half of its strength at temperatures approaching one half of its melting point. In transient heating, however, it takes a finite amount of time for lattice changes in the material to propagate and cause bulk material weakening. Reduction of test data and examination of high speed photographs for contact integrity are being used to establish transient heating guidelines for armature design.

By rewriting equation (2), the energy per volume term can be replaced by the formula for heat generated in a material by a change in temperature. The room temperature value of resistivity is taken as that of the alloy. The resistivity and heat capacity of aluminum is allowed to change with temperature in accordance with temperature variations established for pure aluminum. (Data for the aluminum alloys is insufficient at this time.) The area used for the cross section is established by multiplying the width of the contact by the alternating current skin depth.

$$
\int_{T_{0}}^{T_{f}} \frac{\rho_{M} C_{p} d T}{\rho_{E}(T)}=\int_{o}^{t_{f}}\left(\frac{i}{A}\right)^{2} d t
$$

The new equation may then be solved for $\mathrm{T}_{\mathrm{f}}$ to determine the final temperature an armature launched with a known current vs. time profile reached. Calculations based on 4-and 6-MJ shots have shown that armature temperature has reached $89 \%$ of melting without failing the armature contacts. This was confirmed with high-speed photographs on shots \#2 and 11. For further information on armature development at CEM-UT see reference [6]. A summary of all $90 \mathrm{~mm}$ gun shots to date is presented below in table 1 .

\section{Sample of a Saboted Projectile Test}

Shot \#6 of the $90-\mathrm{mm}$ gun was the first full-scale test of a solid armature launching a separating sabot with an all steel projectile. With four of six available generators operating at $60 \%$ of full energy (23.93 MJ stored in the HPGs), the launch package mass of $2.5 \mathrm{~kg}$

\begin{tabular}{|c|c|c|c|c|c|c|c|c|}
\hline Shot \# & $\begin{array}{l}\text { Date and } \\
\text { Data ID }\end{array}$ & $\begin{array}{c}\text { Muzzle } \\
\text { Velocity } \\
\text { (ms) }\end{array}$ & $\begin{array}{c}\text { Projectile } \\
\text { Mass } \\
(\mathrm{kg})\end{array}$ & $\begin{array}{l}\text { Muzzle } \\
\text { Energy } \\
\text { (MJ) }\end{array}$ & $\begin{array}{c}\text { Peak } \\
\text { Current } \\
\text { (MA) }\end{array}$ & $\begin{array}{c}\text { Peak } \\
\text { kgees }\end{array}$ & $\begin{array}{c}\text { Projectile } \\
\text { Description }\end{array}$ & Comments \\
\hline 1 & $\begin{array}{c}07 / 27 / 88 \\
87 \mathrm{R} 1\end{array}$ & 1 A55 & 1.872 & 20 & 220 & 48.8 & $\begin{array}{l}\text { C-shaped aluminum armature with integral } \\
\text { payload. }\end{array}$ & $\begin{array}{l}\text { Gun performed as predicted. Penetrated } 75 \mathrm{~mm} \text { of mild } \\
\text { steel. }\end{array}$ \\
\hline 2 & $\begin{array}{c}08 / 12 / 88 \\
88 \mathrm{C} 1\end{array}$ & 1,999 & 1.889 & 3.8 & 3.2 & 102.2 & $\begin{array}{l}\text { C-shaped aluminum armature with integral } \\
\text { payload. }\end{array}$ & Gun performed as predicted at full current. \\
\hline 3 & $\begin{array}{c}09 / 02 / 88 \\
8921\end{array}$ & 850 & 2.435 & 0.9 & 0.47 & 1.7 & $\begin{array}{l}\text { C-shaped aluminum armature. Ford dummy } \\
\text { projectile. }\end{array}$ & Short circuit at breech of gun spoiled shot. \\
\hline 4 & $\begin{array}{c}10 / 04 / 88 \\
8 \mathrm{~A} 41\end{array}$ & 1,725 & 2468 & 3.7 & 3.05 & 71.1 & $\begin{array}{l}\text { C-shaped aluminum armature. Ford dummy } \\
\text { projectile. }\end{array}$ & Successful shot. Short circuit did not recur. \\
\hline 5 & $\begin{array}{l}10 / 13 / 88 \\
8 \mathrm{AD} 1\end{array}$ & 1,205 & 2.476 & 1.8 & 3.10 & 73.2 & $\begin{array}{l}\text { C-shaped aluminum armature Kaman non- } \\
\text { separating sabot and dummy dart. }\end{array}$ & Short circuit in laminated bus caused by broken weld. \\
\hline 6 & $\begin{array}{c}12 / 1 / 88 \\
8 \mathrm{C} 11\end{array}$ & 1,724 & 2.467 & 3.7 & 3.01 & 69.3 & $\begin{array}{l}\text { C-shaped aluminum armature Kaman dummy } \\
\text { dart with separating sabot. }\end{array}$ & Successful shot. Penetrating $127 \mathrm{~mm}$ of mild steel. \\
\hline 7 & $\begin{array}{c}12 / 13 / 88 \\
8 \mathrm{CE} 1\end{array}$ & 980 & 1.926 & 0.9 & 1.14 & 472 & $\begin{array}{l}\text { C-shaped aluminum armature with integral } \\
\text { payload. }\end{array}$ & Successful full energy test of a single generator. \\
\hline 8 & $\begin{array}{c}1 / 5 / 89 \\
9154\end{array}$ & 780 & 2480 & 0.8 & 272 & 56.3 & $\begin{array}{l}\text { C-shaped aluminum armature Kaman } \\
\text { tungsten-tipped dart with separating sabot. }\end{array}$ & $\begin{array}{l}\text { Short circuit in isolation switch prevented full current } \\
\text { from reaching gun. }\end{array}$ \\
\hline 9 & $\begin{array}{c}1 / 30 / 89 \\
91 \mathrm{U} 3\end{array}$ & 2,140 & 1.985 & 4.5 & 3.16 & 94.9 & $\begin{array}{l}\text { C-shaped aluminum armature with integral } \\
\text { payload. }\end{array}$ & $\begin{array}{l}\text { Successful shot using isolation switches to stage } \\
\text { generator. }\end{array}$ \\
\hline 10 & $\begin{array}{c}3 / 10 / 89 \\
93 \mathrm{~A} 2\end{array}$ & 1,945 & 2.022 & 3.8 & 3.34 & 104.0 & $\begin{array}{l}\text { C-shaped aluminum armature and integral } \\
\text { payload, fore and aft boreriders. }\end{array}$ & $\begin{array}{l}\text { Early trigger of one isolation switch resulted in reduced } \\
\text { performance. }\end{array}$ \\
\hline 11 & $\begin{array}{c}4 / 14 / 89 \\
94 \mathrm{E} 2\end{array}$ & 2,303 & 2.176 & 5.8 & 3.40 & 100.2 & $\begin{array}{l}\text { C-shaped aluminum armature and integral } \\
\text { payload, fore and aft boreriders. }\end{array}$ & $\begin{array}{l}\text { Early trigger of isolation switch \#3 resulted in reduced } \\
\text { performance. }\end{array}$ \\
\hline 12 & $\begin{array}{c}5 / 15 / 89 \\
95 F 5\end{array}$ & 2,325 & 2.175 & 5.9 & 3.21 & 89.3 & $\begin{array}{l}\text { C-shaped aluminum armature and integral } \\
\text { payload, fore and aft boreriders. }\end{array}$ & $\begin{array}{l}\text { Restrike of one opening switch resulted in reduced } \\
\text { performance. }\end{array}$ \\
\hline 13 & $\begin{array}{c}6 / 15 / 89 \\
96 \mathrm{~F} 2\end{array}$ & 1,969 & 2.258 & 4.4 & 3.27 & 89.1 & $\begin{array}{l}\text { C-shaped aluminum armature and integral } \\
\text { payload, fore and aft boreriders. }\end{array}$ & $\begin{array}{l}\text { Short circuit between breech jumpers reduced } \\
\text { performance. }\end{array}$ \\
\hline 14 & $\begin{array}{c}7 / 25 / 89 \\
97 \mathrm{P3} \\
\end{array}$ & 1,655 & 2.343 & 32 & 275 & 60.7 & $\begin{array}{l}\text { C-shaped aluminum armature and integral } \\
\text { payload, fore and aft boreriders. }\end{array}$ & $\begin{array}{l}\text { Early trigger of isoaltion switch \#3 resulted in reduced } \\
\text { performance. }\end{array}$ \\
\hline 15 & $\begin{array}{l}9 / 18 / 89 \\
991 C\end{array}$ & 1,697 & 2.665 & 3.8 & 297 & 624 & $\begin{array}{l}\text { C-shaped aluminum armature, Kaman } \\
\text { tungsten tipped dart with separating sabot. }\end{array}$ & $\begin{array}{l}\text { Sabot and penetrator began to break up upon } \\
\text { demuzzling. }\end{array}$ \\
\hline 16 & $\begin{array}{c}9 / 28 / 89 \\
9953\end{array}$ & 1,851 & 2.331 & 4.0 & 3.00 & 72.8 & $\begin{array}{l}\text { C-shaped aluminum armature and integral } \\
\text { payload, fore and aft boreriders. }\end{array}$ & $\begin{array}{l}\text { Successful staged shot of three generators. All switches } \\
\text { fired as planned. }\end{array}$ \\
\hline 17 & $\begin{array}{c}10 / 18 / 89 \\
9 \text { AI4 }\end{array}$ & 1,623 & 2.674 & 3.5 & 295 & 61.4 & $\begin{array}{l}\text { C-shaped aluminum armature, Kaman } \\
\text { tungsten tipped dart with separating sabot. }\end{array}$ & Generators successfully staged. Penetrator came apart. \\
\hline 18 & $\begin{array}{c}11 / 1 / 89 \\
9 \mathrm{~B} 12\end{array}$ & 1,605 & 2.350 & 3.0 & 282 & 63.8 & $\begin{array}{l}\text { C-shaped aluminum armature and integral } \\
\text { payload, fore and aft boreriders. }\end{array}$ & $\begin{array}{l}\text { Generators successfully staged. Insulation failure in } \\
\text { laminated busbar diverted current from armature. }\end{array}$ \\
\hline 19 & $\begin{array}{c}12 / 8 / 89 \\
9 \mathrm{C} 83 \\
\end{array}$ & 2,110 & 2.393 & 5.3 & 3.15 & 78.2 & $\begin{array}{l}\text { C-shaped aluminum armature and integral } \\
\text { payload, fore and aft boreriders. }\end{array}$ & $\begin{array}{l}\text { Generators successfully staged. Fault to ground and } \\
\text { reduced current to gun. }\end{array}$ \\
\hline
\end{tabular}

Table 1. Summary of Task B, $90 \mathrm{~mm}$ railgun tests 
was accelerated to a muzzle velocity of $1,724 \mathrm{~m} / \mathrm{s}$. The resulting muzzle energy was 3.67 MJ. Total system efficiency was $15.3 \%$. The solid armature was $944 \mathrm{~g}$ or $38 \%$ of the total package mass. Peak current into the gun was 3.01 MA, resulting in a peak acceleration of 69.3 kgees. The armature and projectile exited the muzzle intact, although the sabot was cracked. Because the $\mathrm{x}$-rays were taken $3.5 \mathrm{~m}$ from the muzzle, it was not clear what condition the sabot was in at exit. The target, a $13 \mathrm{~cm}$ thick plate of mild steel, was penetrated by the projectile which proceeded to make a $5 \mathrm{~cm}$ deep impact crater in a steel backup plate. Figures 5 through 9 illustrate a portion of the information gathered after shot \#6.

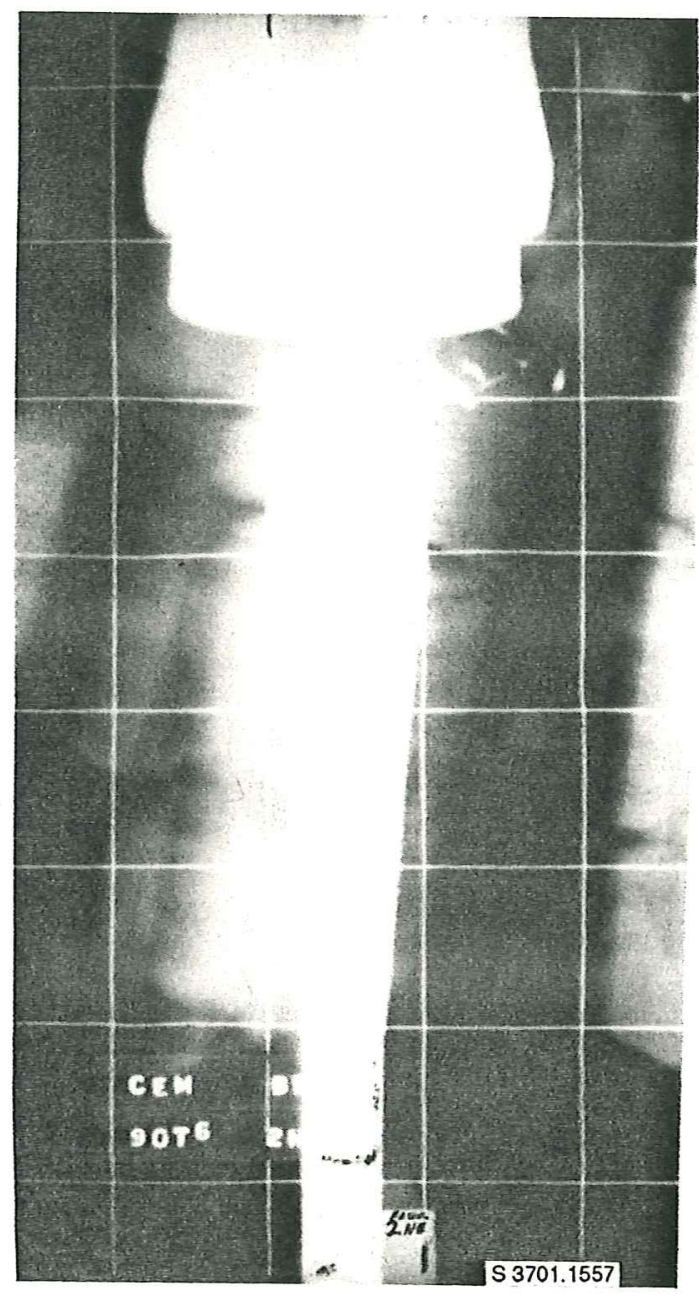

Figure 5. X-ray of armature and projectile taken on shot \#6 of 90-mm gun

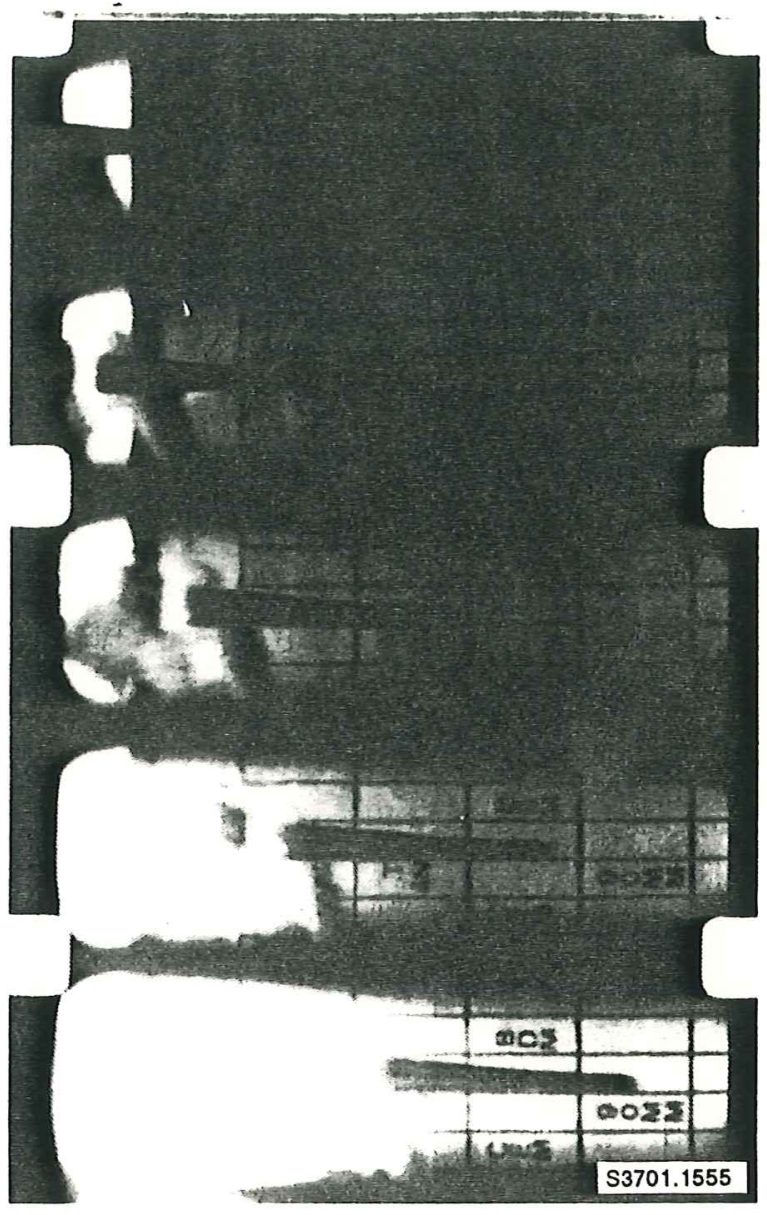

Figure 6. High-speed film taken of projectile in flight on shot \#6 of $90-\mathrm{mm}$ gun

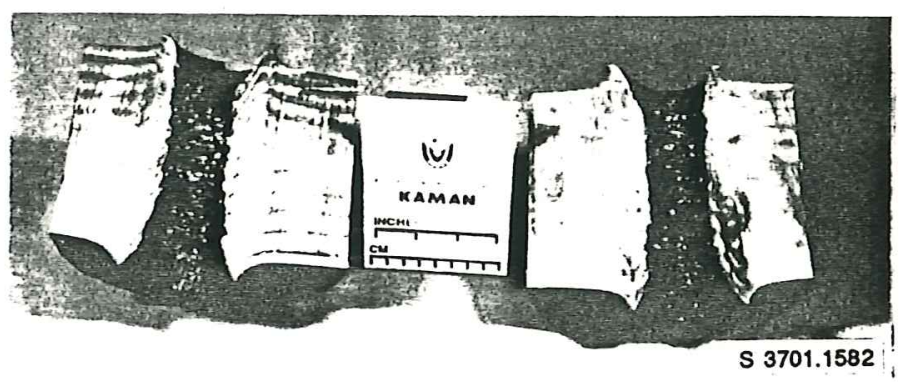

Figure 7. Five inch thick steel target penetrated by Kaman Sciences projectile fired on shot \#6 of 90-mm gun 


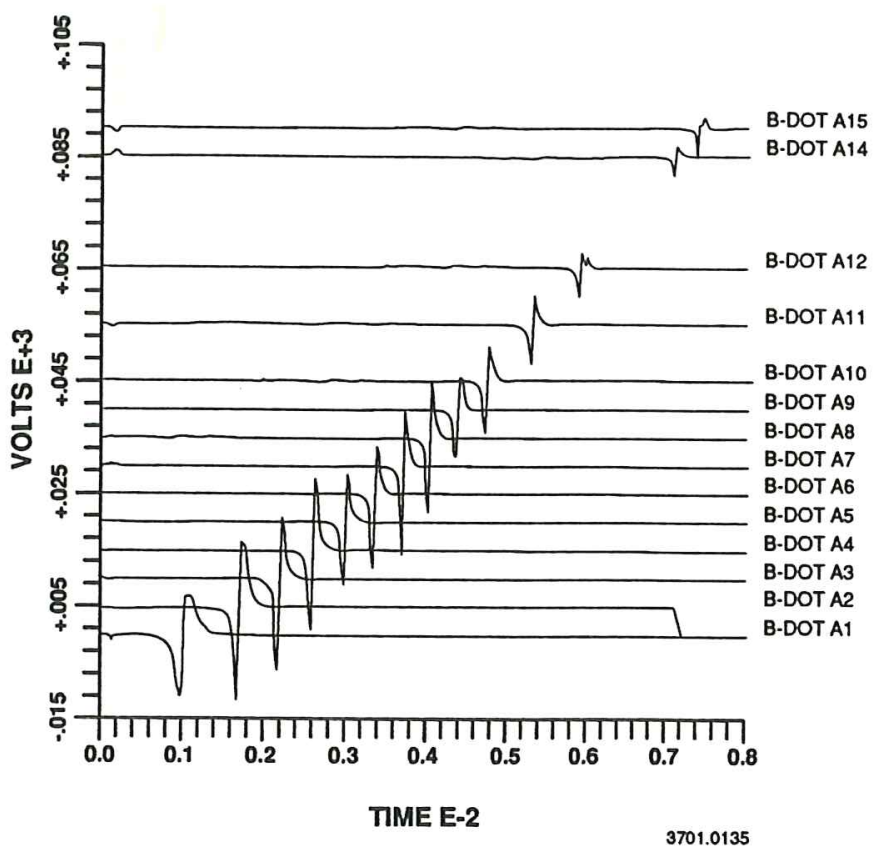

Figure 8. B-dot traces recorded on shot \#6

\begin{tabular}{|cccccc|}
\hline $\begin{array}{c}\text { ENERGY } \\
\text { STORE }\end{array}$ & 2 & 3 & 5 & 6 & TOTAL \\
\hline \hline HPG IPm & 4,695 & 4,684 & 4,673 & 4,680 & \\
\hline \hline $\begin{array}{c}\text { HPG STORED } \\
\text { ENERGY (MJ) }\end{array}$ & 6 & 5.99 & 5.96 & 5.98 & 23.93 \\
\hline \hline $\begin{array}{c}\text { PEAK CUURRENT } \\
\text { (KA) }\end{array}$ & 960 & 958 & 976 & 955 & \\
\hline \hline $\begin{array}{c}\text { INDUCTIVE ENERGY } \\
\text { BEFORE SWITCHING } \\
\text { (MJ) }\end{array}$ & 2.76 & 2.75 & 2.86 & 2.74 & 11.1 \\
\hline $\begin{array}{c}\text { HPG TO INDUCTOR } \\
\text { TRANSFER } \\
\text { EFFICIENCY }\end{array}$ & $46 \%$ & $46 \%$ & $48 \%$ & $46 \%$ & $\begin{array}{c}46.5 \% \\
\text { avg. }\end{array}$ \\
\hline \hline $\begin{array}{c}\text { CURRENT AFTER } \\
\text { SWITCHING (KA) }\end{array}$ & 840 & 850 & 854 & 830 & \\
\hline \hline $\begin{array}{c}\text { INDUCTIVE ENERGY } \\
\text { AFTER SWTCHING } \\
\text { (MJ) }\end{array}$ & 2.12 & 2.17 & 2.19 & 2.07 & 8.55 \\
\hline \hline $\begin{array}{c}\text { TOTAL BREECH } \\
\text { ENERGY (MJ) }\end{array}$ & & & & & 7.95 \\
\hline \hline $\begin{array}{c}\text { PROJECTILE } \\
\text { KE (MJ) }\end{array}$ & & & & & 3.67 \\
\hline
\end{tabular}

Figure 9. Energy balance conducted after shot \#6

\section{Conclusions}

Perhaps the most important conclusion reached as a result of the $90 \mathrm{~mm}$ gun tests at CEM-UT is that Electromagnetic guns with solid armatures can be an efficient method for launching projectiles weighing 1 to 2 $\mathrm{kg}$ at high velocities. While some of the initial goals of the experiment have not been reached as yet, those goals, $9 \mathrm{MJ}$ of muzzle energy, velocities of 3 to $4 \mathrm{~km} / \mathrm{s}$, are attainable. The rail insertion technique has been verified. The $90-\mathrm{mm}$ gun and associated buswork have been tested at full current. Generator staging has been tested. Solid armatures have been launched at $6 \mathrm{MJ}$ and saboted projectile packages have been launched at $4 \mathrm{MJ}$. In addition to these accomplishments, a great deal has been learned about the use of a variety of materials in the harsh environment associated with a high energy railgun experiment.

\section{Acknowledgments}

Research funding for this program was provided by Defense Advanced Research Projects Agency (DARPA) and U.S. Army Armament Research, Development, and Engineering Center (ARDEC) under contract number DAAA21-86-C-0215.

Kaman Sciences and Ford Aerospace provided projectiles during the $90 \mathrm{~mm}$ single shot gun experiment.

Without valuable contributions from the following individuals this paper would not have been possible: Jon Hahne, Tom Hotz, John Kajs, Lori Moore, Dennis Peterson, John Price, Jim Upshaw, and Dave Wehrlen.

\section{References}

[1] R.C. Zowarka, Jr., D.R. Peterson, J.H. Price and W.F. Weldon "9 MJ Laboratory Gun and Range at The University of Texas at Austin", IEEE Transactions on Magnetics, vol 25, no. 1, January 1989 pp 653-661.

[2] L.M. Barker and T.G. Trucano, "Railgun Rail Gouging by Hypervelocity Sliding Contact", IEEE Transactions on Magnetics, vol 25, no. 1, January 1989, pp 83-87.

[3] Doris Kuhlmann-Wilsdorf, J. Cuadros and M.E. Skidmore, "Hybrid Armatures: A New Type of High Speed High-Current Conduction Across Sliding Contacts", Proceedings 1987 International Current Collector Conference, November 1987.

[4] R.C. Zowarka, Jr., "Electrical Energy Gun System Study," Report of the Propulsion and Power Conditioning Panel of the Electric Gun System Study to David C. Hardison, Study Director, David Elliott, Ed., Jet Propulsion Laboratory, JPL D-6272, May 15, 1989.

[5] M.W. Ingram and J.H. Price, "Large and Small Caliber Solid Armatures: Experimental Results," to be presented at the 5th Symposium on Electromagnetic Launch Technology, Eglin AFB, FL, April 2-5, 1990. 